\title{
IGF-I activates caspases 3/7, 8 and 9 but does not induce cell death in colorectal cancer cells
}

\author{
Shi Yu Yang*1, Capucine Bolvin ${ }^{1}$, Kevin M Sales ${ }^{1}$, Barry Fuller ${ }^{1}$, \\ Alexander M Seifalian ${ }^{1}$ and Marc C Winslet ${ }^{1,2,3}$
}

\begin{abstract}
Address: ${ }^{1}$ University College London, Division of Surgery and Interventional Science, Royal Free \& University College Medical School, Rowland Hill Street, London, NW3 2PF, UK, ${ }^{2}$ Royal Free Hampstead NHS Trust Hospital, London, UK and ${ }^{3}$ University College NHS Hospital, London, UK

Email: Shi Yu Yans* - shiyu.yang@medsch.ucl.ac.uk; Capucine Bolvin - c.bolvin@medsch.ucl.ac.uk; Kevin M Sales - k.sales@medsch.ucl.ac.uk; Barry Fuller - b.fuller@medsch.ucl.ac.uk; Alexander M Seifalian - a.seifalian@medsch.ucl.ac.uk; Marc C Winslet - m.winslet@medsch.ucl.ac.uk

* Corresponding author
\end{abstract}

Published: 2I May 2009

BMC Cancer 2009, 9:158 doi:10.1186/147|-2407-9-158

This article is available from: http://www.biomedcentral.com//47/-2407/9//58

(C) 2009 Yang et al; licensee BioMed Central Ltd.

This is an Open Access article distributed under the terms of the Creative Commons Attribution License (http://creativecommons.org/licenses/by/2.0), which permits unrestricted use, distribution, and reproduction in any medium, provided the original work is properly cited.
Received: 16 September 2008

Accepted: 21 May 2009

\begin{abstract}
Background: Colorectal cancer is the third most common cancer in the western world. Chemotherapy is often ineffective to treat the advanced colorectal cancers due to the chemoresistance. A major contributor to chemo-resistance is tumour-derived inhibition or avoidance of apoptosis. Insulin-like growth factor I (IGF-I) has been known to play a prominent role in colorectal cancer development and progression. The role of IGF-I in cancer cell apoptosis is not completely understood.
\end{abstract}

Methods: Using three colorectal cancer cell lines and one muscle cell line, associations between IGF-I and activities of caspase 3/7, 8 and 9 have been examined; the role of insulin-like growth factor I receptor (IGF-IR) in the caspase activation has been investigated.

Results: The results show that exogenous IGF-I significantly increases activity of caspases 3/7, 8 and 9 in all cell lines used; blocking IGF-I receptor reduce IGF-I-induced caspase activation. Further studies demonstrate that IGF-I induced caspase activation does not result in cell death. This is the first report to show that while IGF-I activates caspases 3/7, 8 and 9 it does not cause colorectal cancer cell death.

Conclusion: The study suggests that caspase activation is not synonymous with apoptosis and that activation of caspases may not necessarily induce cell death.

\section{Background}

Normal human colon consists of many crypts; each crypt contains several thousand differentiated cells and a small number of stem cells. Stem cells reside at the bottom of the crypts and divide slowly and systemically, whereas differentiated cells divide rapidly and travel to the top of the crypt. Each day a total of approximately $10^{10}$ cells are shed into the colon lumen through apoptosis [1]. Apoptosis is therefore crucial for the maintenance of normal colon morphology and function. When programmed cell death does not occur appropriately in the colon, cells that should be eliminated might persist, become neoplastic and subsequently develop into colorectal cancer (CRC).

CRC is the third most common cancer in the western world. Despite advances in the management of this con- 
dition, including improved surgical techniques, the use of chemo or radiotherapy and, more recently, the use of screening, the mortality has not changed for decades. At least $40 \%$ of patients with colorectal cancer develop metastases; chemotherapy alone or in combination with radiotherapy is usually used as an adjuvant therapy to surgery for the advanced disease [2]. These approaches, however, are not highly effective against disseminated colorectal metastases [3]. The major contributor to the limited effectiveness of treatment is cancer cell resistance to current chemotherapeutic agents. The most important mechanism which contributes to chemo-resistance is the inhibition or avoidance of drug-induced apoptosis.

Caspases play a central role in most apoptotic cell death, however there is evidence indicated that caspases also involve with non-apoptotic function. For example, caspase 3 activity is required for skeletal muscle differentiation [4] and terminal differentiation of HT-29 colon cancer cells is tightly linked to caspase activation [5]. Caspases also play roles in cell motility, migration and some cell enucleation [6].

It has been established that IGF-I regulates intestinal epithelial cell proliferation, differentiation [7] and that IGF signalling plays a prominent role in cancer development and progression [8-10]. Although many studies have shown that IGF-I is an anti-apoptotic protein, the role of IGF-I in cellular apoptosis is not completely understood. Previous studies have shown that IGF-I fully protected HT-29-D4 colon carcinoma cells undergoing apoptosis induced by tumour necrosis factor- $\alpha$ [11]. Disrupting the interaction between IGF-I and its receptor (IGF-IR) with an IGF-I receptor antagonist significantly increased colon cancer cell apoptosis [12]. There were also some observations, however, showing that IGF-I enhances the apoptotic response to anti-Fas antibody in colorectal cancer cells [13], potentiates tumour necrosis factor- $\alpha$ induced apoptosis in adipose-like cells [14], induces apoptosis in mouse fibroblast cells in the medium with low concentration of serum [15], and also in mouse skeletal muscle cells in the presence of tumour necrosis factor- $\alpha$ (TNF- $\alpha$ ) [16]. The precise mechanisms by which IGF-I receptors signal to apoptotic pathways are still unclear. Given the fact that the IGF system has become an attractive molecular target for anticancer therapies, it is necessary and important to determine the relationship between IGF-I pathways and apoptotic pathways.

We have examined the effect of IGF-I on the activities of caspase 8,9 and 3/7 in three colorectal cancer and one skeletal muscle cell lines. Although these cell lines have different origins, tissue types, cell types and molecular features (table 1), exogenous IGF-I increased the activities of caspase $3 / 7,8$ and 9 in all of these cell lines and it appear that the IGF-I receptor is involved in caspase activation and the caspase activation does not result in cell death.

\section{Methods \\ Reagents}

Recombinant human IGF-I was purchased from Peprotech EC Ltd (UK). IGF-IR antibody was purchased from ab-cam (product code: ab16817, Cambridge, UK). Caspase 3/7, Caspase 8 and Caspase 9 activity assay kits and CellTiter-Blue cell viability assay kits were purchased from Promega (Madison, USA). Yo Pro-1 iodide was purchased from Invitrogen (Paisley, UK). Alamar Blue cell proliferation assay kit was purchased from Serotec Ltd (Oxford, UK). General Caspase inhibitor, Z-VAD-FMK was purchased from R \& D System (Oxford, UK). General mouse IgG was purchased from Sigma (product number I 5381, Dorset, UK). All cell culture media, serums and antibiotics were purchased from GIBCO (UK).

\section{Cell lines and culture conditions}

The human colon cancer cell lines HT-29, HCT-116, SW620 and mouse skeletal muscle cell line $\mathrm{C}_{2} \mathrm{C}_{12}$ were purchased from European Collection of Cell Cultures (ECACC). HT-29 and HCT-116 cells were cultured in McCoy's 5A medium containing $2 \mathrm{mM}$ glutamine, 10\% foetal bovine serum and $1 \%$ penicillin and streptomycin. SW620 cells were cultured in L-15 medium containing 2 $\mathrm{mM}$ glutamine, $10 \%$ foetal bovine serum and $1 \%$ penicillin and streptomycin. $\mathrm{C}_{2} \mathrm{C}_{12}$ cells were cultured in DMEM medium containing $10 \%$ foetal bovine serum and $1 \%$ penicillin and streptomycin. All cells were cultured and

Table I: Origins, tissue types, cell types and molecular features of cell lines used in the experiment

\begin{tabular}{lllllll}
\hline Cell line & Species & Tissue & Cell Type & APC & P53 & TGF- $\beta$ IIR \\
\hline HT-29 & Human & Colon & Epithelial & mut & mut & wt \\
\hline HCT-116 & Human & Colon & Epithelial-like & wt & wt & mut \\
\hline SW620 & Human & Colon & Epithelial & mut & mut & wt \\
\hline $\mathrm{C}_{2} \mathrm{C}_{12}$ & Mouse & Muscle & Myblast & wt & wt & wt \\
\hline
\end{tabular}


maintained at $37^{\circ} \mathrm{C}$ with $5 \% \mathrm{CO}_{2} / 95 \%$ air and used at passages 3-8 after their receipt from the supplier.

\section{Cell treatments}

\section{IGF-I treated cell}

All cells were seeded on 96 well plates with appropriate media (HT-29, HCT-116 cells with McCoy's 5A medium, SW620 cells with L-15 medium and $\mathrm{C}_{2} \mathrm{C}_{12}$ cells with DMEM medium) containing $10 \%$ foetal bovine serum and $1 \%$ penicillin and streptomycin at the density of $2 \times$ $10^{4}$ cells/well. After 24 hours of culture, HT-29 cells were treated with different concentrations $(0,1,10$ and $100 \mathrm{ng} /$ $\mathrm{ml}$ ) of IGF-I (Peprotech EC Ltd, UK) for 24 or 48 hours with serum containing medium (SCM, McCoy's 5A medium containing 10\% foetal bovine serum and 1\% penicillin and streptomycin) and serum free medium (SFM, McCoy's 5A medium containing $1 \%$ penicillin and streptomycin) respectively. HCT-116, SW620 and $\mathrm{C}_{2} \mathrm{C}_{12}$ cells were treated with concentration of 0 and $50 \mathrm{ng} / \mathrm{ml}$ of IGF-I for 48 hours with SCM and SFM respectively. After completion of treatment, cells were subjected to assays for apoptosis, cell death and cell viability (see following section).

\section{IGF-IR antibody neutralizing IGF-I actions in cancer cells}

Cells were seeded onto 96 well plates with appropriate media (HT-29 cells with McCoy's 5A medium and SW620 cells with L-15 medium) containing $10 \%$ foetal bovine serum and $1 \%$ penicillin and streptomycin at the density of $2 \times 10^{4}$ cells/well. After 24 hours of culture, cells were incubated with IGF-IR antibody (product code: ab16817, ab-cam, Cambridge, UK) within SCM or SFM medium respectively at $37^{\circ} \mathrm{C}$ with $5 \% \mathrm{CO}_{2} / 95 \%$ air for $30 \mathrm{~min}$ utes. IGF-I was then added to the wells. The final concentration of IGF-IR antibody in the medium was $400 \mathrm{ng} / \mathrm{ml}$ and IGF-I concentration was $50 \mathrm{ng} / \mathrm{ml}$. Cells were incubated with IGF-IR antibody and IGF-I for further 48 hours followed by analysis for apoptotic and cell death assays. A general mouse IgG was also included in the experiment to check whether any IGF-IR antibody neutralization of IGFI action is a specific effect.

\section{Caspase activity assay}

Following treatments cells were subjected to Caspase 3/7, 8, 9 activities measurement with Caspase-Glo assay kit (Promega, Madison USA). Briefly, the plates containing cells were removed from the incubator and allowed to equilibrate to room temperature for 30 minutes. $100 \mu \mathrm{l}$ of Caspase-Glo reagent was added to each well, the content of well was gently mixed with a plate shaker at 300-500 rpm for 30 seconds. The plate was then incubated at room temperature for 2 hours. The luminescence of each sample was measured in a plate-reading luminometer (Thermo Labsystems) with parameters of 1 minute lag time and 0.5 second/well read time. The experiments were performed in triplicate and repeated on two separately-initiated cultures.

\section{Establishment and validation of cell death assay for colorectal cancer cell lines (HT-29, SW620 and HCTII6)}

In order to investigate whether the caspase activation induces cell death, a previously reported cell death assay [13] was employed to establish cell death assessment for HT-29, SW620 and HCT116 cells. Briefly HT-29, SW620 and HCT116 cells were seeded in 96 well plate for 24 hours and then treated with different concentrations (37.5, 70, 150 and $300 \mu \mathrm{M})$ of 5-Fluorouracil (5-FU) which have been shown to be able to induce apoptosis in these cell lines [17-19]. After 48 hours treatment, YO PRO-iodide (Invitrogen) was added to each well at a final concentration of $4.0 \mu \mathrm{M} / \mathrm{L}$ and the plates were incubated at $37^{\circ} \mathrm{C}$ for further 4 hours. The fluorescence was determined on a fluorescent plate reader (Fluoroskan Ascent FL; Labsystems, Helsinki, Finland). For the comparison purpose the cell death index for treated and untreated cells was calculated with the formula:

$$
\text { Cell death index }=\mathrm{Ft} / \mathrm{Fc}
$$

where Ft and Fc represent the units of fluorescence (RLU) in the treated and the untreated cells respectively. The untreated cell death index would be $1(\mathrm{Fc} / \mathrm{Fc})$. A cell death index $>1$ in the treated cells would indicate more cell death in the treated group.

\section{Cell death assay}

Cells were seeded onto 96 well plates with appropriate media (HT-29 and HCT116 cells with McCoy's 5A medium and SW620 cells with L-15 medium) containing $10 \%$ foetal bovine serum and $1 \%$ penicillin and streptomycin at the density of $2 \times 10^{4}$ cells/well. After 24 hours of culture, cells were treated with IGF-I at $100 \mathrm{ng} / \mathrm{ml}$ concentration for 48 hours and then subjected to the cell death assay using the above methods.

\section{Cell viability assay}

A previously reported cell viability assay [20] was employed to assess the number of viable cell after IGF-I treatment. Briefly cells were seeded onto 96 well plates with appropriate media (HT-29 and HCT116 cells with McCoy's 5A medium and SW620 cells with L-15 medium) containing $10 \%$ foetal bovine serum and $1 \%$ penicillin and streptomycin at the density of $2 \times 10^{4}$ cells/well. Following 24 hours of culture, cells were treated with IGF-I at the concentration of $100 \mathrm{ng} / \mathrm{ml}$ for 48 hours. After treatment $20 \mu \mathrm{l}$ of CellTiter-Blue reagent (Promega, Madison USA) was added to each well and mixed for 2 minute on orbital shaker. Cells were further incubated at $37^{\circ} \mathrm{C}$ with $5 \% \mathrm{CO}_{2} / 95 \%$ air for 4 hours. The fluorescence was measured with excitation at 530 and emission at $620 \mathrm{~nm}$. The 
CellTiter-Blue cell viability assay provides a fluorometric method for estimating the number of viable cells. Living cells posses the ability to reduce resazurin into resosurfin, which is highly fluorescent. Nonviable cells, due to loss of metabolic capacity, do not reduce the CellTiter-Blue reagent and thus do not generate a fluorescent signal.

\section{Inhibition of caspases and cell proliferation assay}

In order to investigate whether IGF-I-induced caspase activation has any effect on cancer cell proliferation, a general caspase inhibitor, Z-VAD-FMK (R \& D System, Oxford, UK) was used to inhibit caspase activity induced by exogenous IGF-I. Briefly cells were seeded onto 96 well plates with appropriate media (HT-29 and HCT116 cells with McCoy's 5A medium and SW620 cells with L-15 medium) containing $10 \%$ foetal bovine serum and $1 \%$ penicillin and streptomycin at the density of $2 \times 10^{4}$ cells/well. Following 24 hours of culture, cells were treated with either IGF-I $(100 \mathrm{ng} / \mathrm{ml})$ only or IGF-I $(100 \mathrm{ng} / \mathrm{ml})$ plus Z-VADFMK $(100 \mu \mathrm{M})$ for 48 hours. After treatment, $20 \mu \mathrm{l}$ of Alamar blue (Serotec Ltd, Oxford, UK) was added to each well and mixed for 2 minute on orbital shaker. Cells were further incubated at $37^{\circ} \mathrm{C}$ with $5 \% \mathrm{CO}_{2} / 95 \%$ air for 4 hours. The fluorescence was measured with excitation at 530 and emission at $620 \mathrm{~nm}$. Alamar blue assay is a redox method to measure the proliferation of various human and animal cell lines and has been proposed as an alternative method to MTT assay [21].

\section{Statistical Analysis}

All data have been examined and followed a normal distribution. All results were expressed as mean \pm SEM. One way ANOVA (Prism version 42004 edition, USA) with multiple comparison test was used. Statistical analysis was perform on $\mathrm{n}=6$ samples and Bonferroni's Multiple Comparison Test was used after ANOVA. $\mathrm{P}<0.05$ is considered as significant and indicated as *; $\mathrm{P}<0.01$ is considered as higher significance and indicated as **. P $>0.05$ is considered as not significant and marked as NS.

\section{Results \\ IGF-I increased caspases 3/7, 8 and 9 activities in colorectal cancer cells}

To assess the effect of IGF-I on the activities of the main caspases (caspase 3/7, 8 and 9) in colorectal cancer cells, we treated the human HT-29 cell line with different concentrations of recombinant human IGF-I for 24 and 48 hours. The caspase activity was evaluated with cell-based homogeneous caspase-glo assay kit in serum containing medium (SCM, figure $1 \mathrm{a}-\mathrm{f}$ ) and serum free medium (SFM, figure $1 \mathrm{~g}-\mathrm{l}$ ). The results shown that after treatment with IGF-I for 24 and 48 hours, HT-29 cellular caspase 3/ 7 activities increased in both SCM and SFM conditions in a dose dependent manner (figures $1 \mathrm{a}, \mathrm{b}, \mathrm{g}$ and $1 \mathrm{~h}$ ). It has been recognized that caspase $3 / 7$ is activated by caspases
8 or 9 , therefore these two caspases activity was also measured using the same methods under the same conditions (SCM and SFM). The results demonstrate that after treatment with IGF-I, the activity of the caspase 8 (figures $1 \mathrm{c}$, $\mathrm{d}, \mathrm{i}$ and $1 \mathrm{j}$ ) and 9 (figure $1 \mathrm{e}, \mathrm{f}, \mathrm{k}$ and $1 \mathrm{l}$ ) also increased in SCM and SFM conditions in a dose dependant manner. Caspase 8 activation is the step immediately following death-inducing signalling complex (DISC) formation. The latter is the part of the extrinsic apoptosis pathway which involves death ligands bound to cell surface death receptors. Caspase 9 activation is a part of the intrinsic apoptosis pathway, which involves cytochrome $\mathrm{C}$ release from the mitochondria [22]. It is interesting to note that although IGF-I increased in all three caspases $(3 / 7,8$ and 9) activities in both SCM and SFM conditions, the level of these caspases activity in SFM conditions (figure 1g-l) is considerably higher than those in SCM conditions (figure 1a-f). This finding is consistent with a previous report which demonstrated that serum deprivation induced apoptosis [14]. Collectively these data suggested that IGFI treatment increases human colon cancer HT-29 cell caspase 3/7, 8 and 9 activity under both SCM and SFM conditions.

To gain further insight into the IGF-I induced caspase activation with other cells; we extended the experiments to SW620 and HCT-116 colorectal tumour cells and $\mathrm{C}_{2} \mathrm{C}_{12}$ myoblast cells. The results demonstrate that addition of IGF-I also significantly increased activity of caspase 3/7 (figure 2a), 8 (figure 2b) and 9 (figure 2c) in HCT-116 CRC cells in both SCM and SFM conditions. For SW620 and $\mathrm{C}_{2} \mathrm{C}_{12}$ cells inclusion of IGF-I in both serum containing and serum free medium also significantly increased caspase $3 / 7$ activities (figure $2 \mathrm{~d}$ and $2 \mathrm{e}$ ). Although the cellular properties (including species, tissue type, cell type and gene mutations) in four cell lines used are heterogeneous (table 1), IGF-I universally increased caspase activities in all four cell lines.

\section{IGF-I activate caspases $3 / 7,8$ and 9 in colon cancer cells via IGF type I receptor}

To elucidate whether IGF-I activation of caspases $3 / 7,8$ and 9 is due to the interaction between IGF-I and its receptors, a neutralised anti-IGF type 1 receptor antibody (IGFIR $\mathrm{ab}$ ) was used to interfere with the binding of IGF-I to its receptors in cells. The results show that after 48 hours of IGF-I treatment the activity of caspases $3 / 7,8$ and 9 in HT29 cells significantly increased in both SCM (figure 3a, c and $3 e$ ) and SFM (figure $3 b, d$ and $3 f$ ) mediums. When IGF-IR ab was included in the IGF-I treated cells, the caspase $3 / 7$ activities significantly decreased $(P<0.05)$ in both SCM (figure 3a) and SFM (figure 3b) mediums compared to IGF-I treated groups, while the caspase 8 and 9 activities significantly decreased $(P<0.01)$ in both SCM (figure $3 c$ and $3 e$ ) and SFM (figure $3 d$ and $3 f$ ). All these 


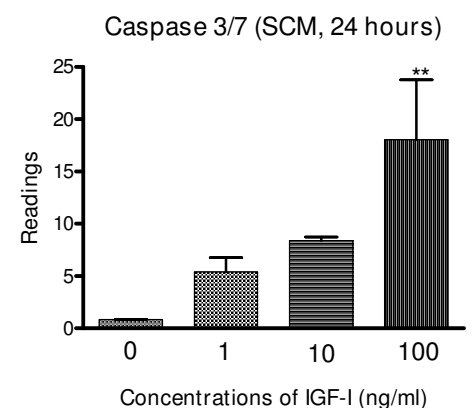

a

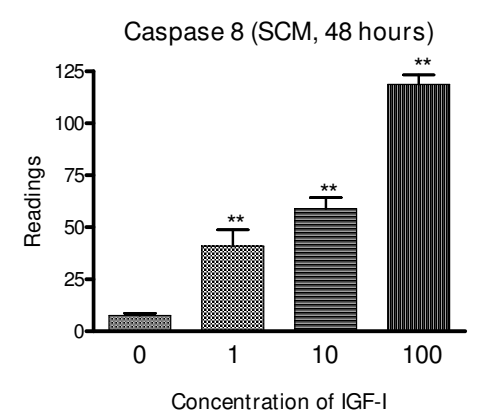

d

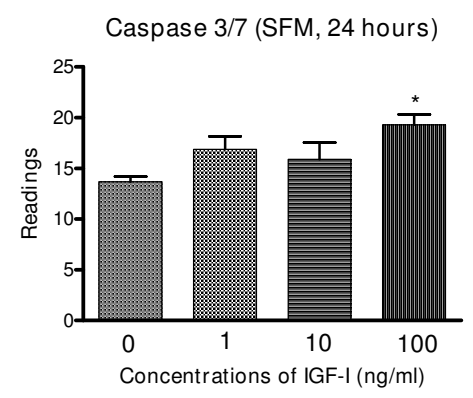

g

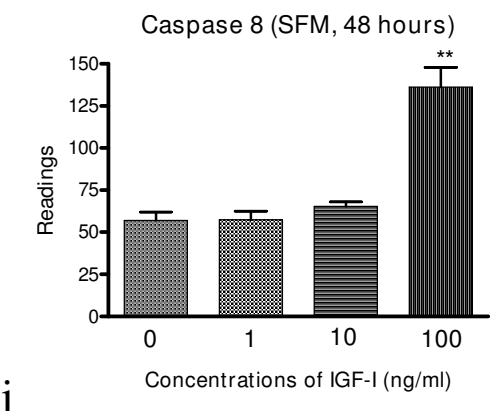

Caspase 3/7 (SCM, 48 hours)

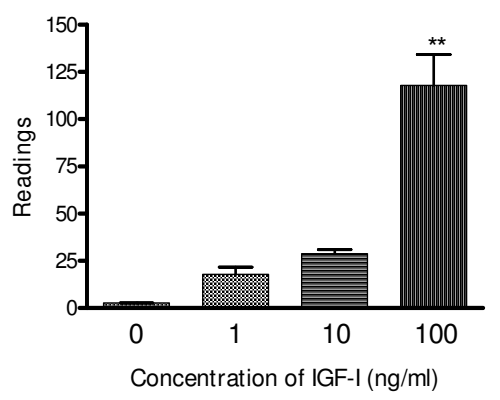

b

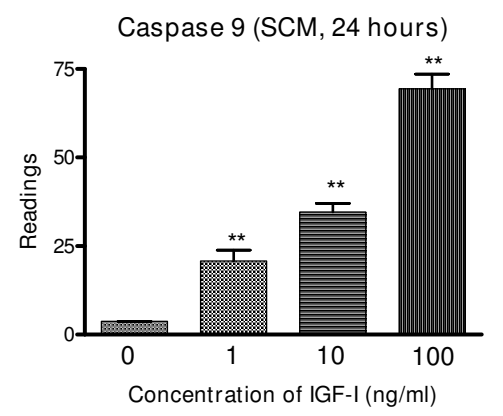

e

Caspase 3/7 (SFM, 48 hours)

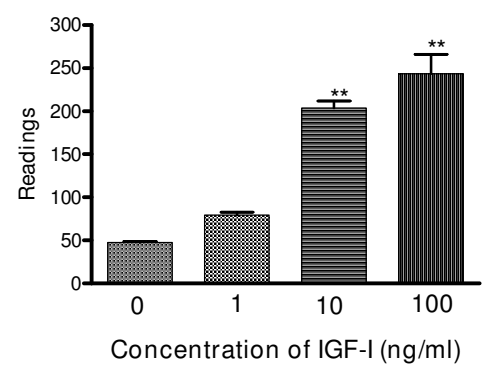

Caspase 9 (SFM, 24 hours)

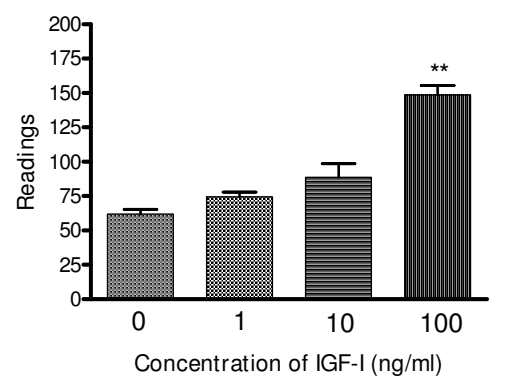

Caspase 8 (SCM, 24 hours)

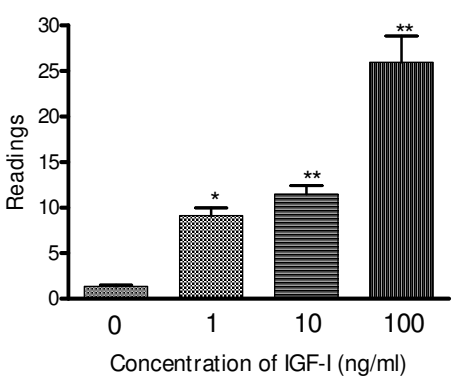

$\mathrm{C}$

Caspase 9 (SCM, 48 hours)

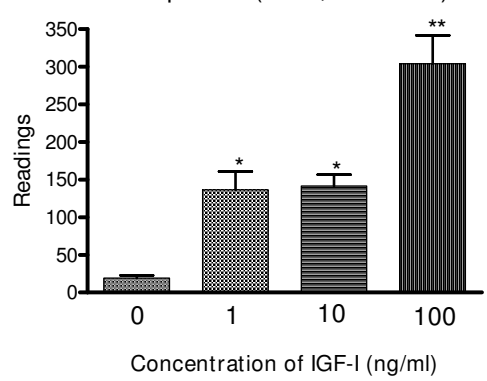

Caspase 8 (SFM, 24 hours)

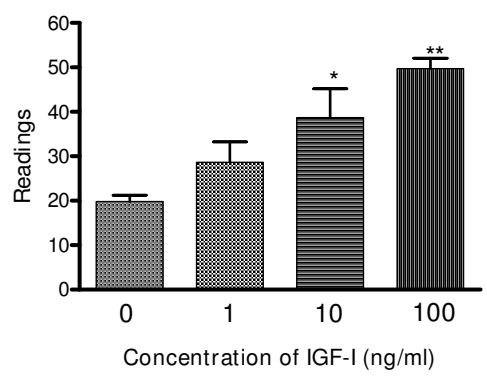

Caspase 9 (SFM, 48 hours)

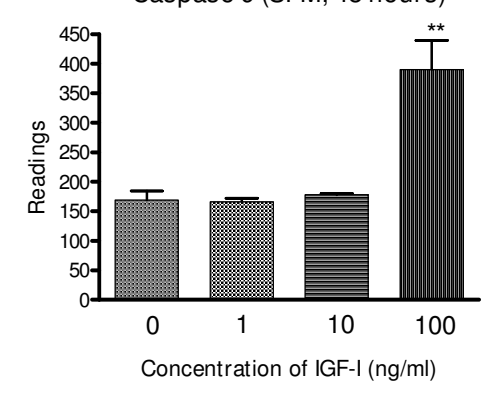

Figure I

IGF-I activate caspases 3/7, 8 and 9 in HT-29 cells. IGF-I activate caspases 3/7 (a, b, g, h), 8 (c, d, i, j) and 9 (e, f, k, I) in HT-29 cells in serum containing (SCM, a-f) and serum free (SFM, g-l) media following the treatment with different concentrations of IGF-I (I, I0, and I00 ng/ml) for 24 and 48 hours. Significance value: $* P<0.05$; ** $P<0.01$ compared to untreated cells. 
Caspase 3 (HCT-116, 48 hours)

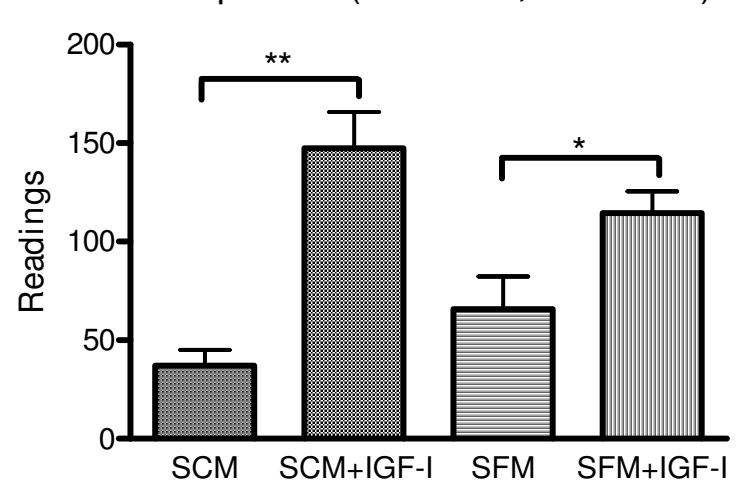

a

Caspase 9(HCT-116, 48 hours)

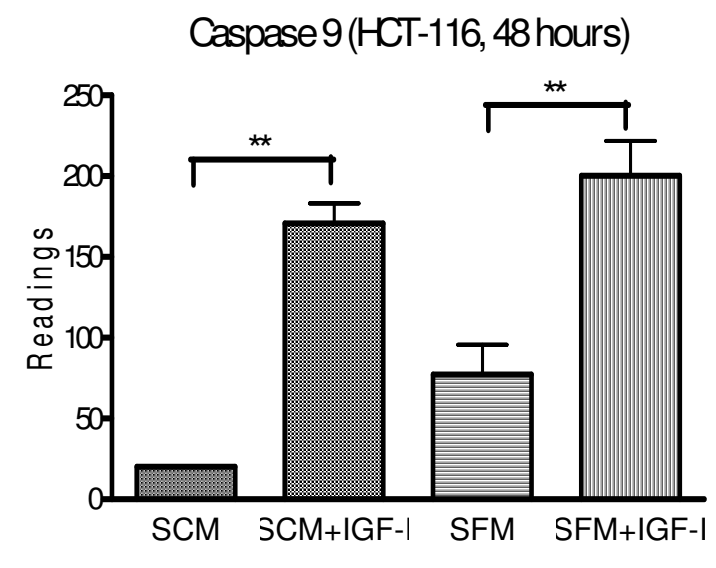

c

\section{Caspase 3(C2C12, 48hours)}

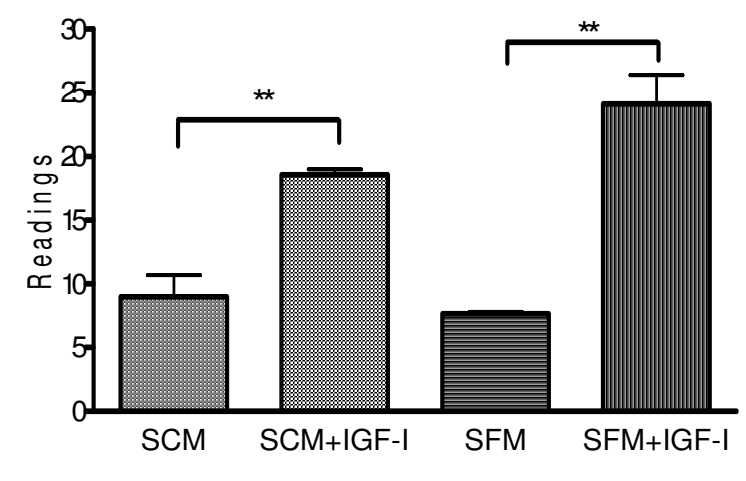

Caspase 8 (HCT-116, 48 hours)

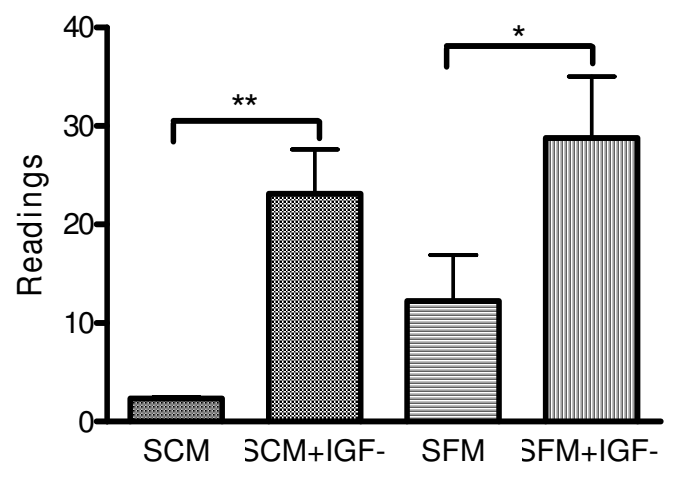

Caspase 3(SM620, 48hours)

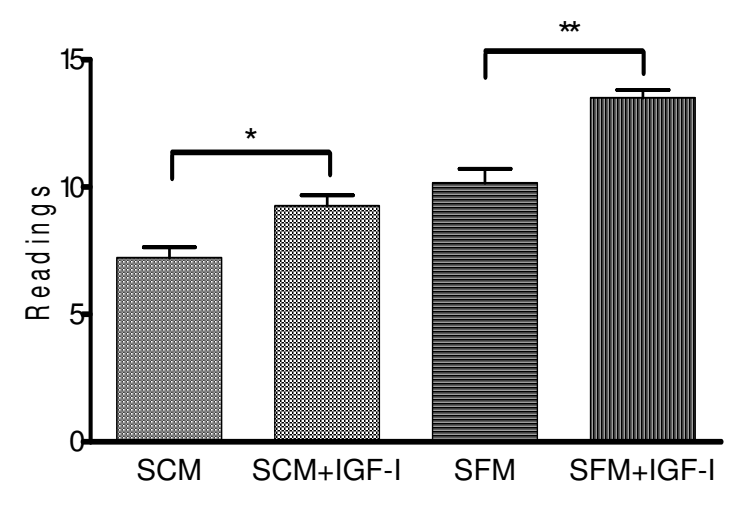

Figure 2

IGF-I activate caspases 3/7, 8 and 9 in HCTI I6, SW620 and C2CI 2 cells IGF-I activate caspase 3/7 (a), 8(b) and 9 (c) in serum containing media (SCM) and serum free medium (SFM) in HCT II 6 cells following the treatment with IGF-I (50 ng/ml) for 48 hours. IGF-I activate caspase 3/7 in SW620 cells (d) and $C_{2} C_{12}$ cells (e) in serum containing media (SCM) and serum free media (SFM) for 48 hours. Significance value: $* P<0.05$; $* *<<0.01$ compared to untreated cells. 

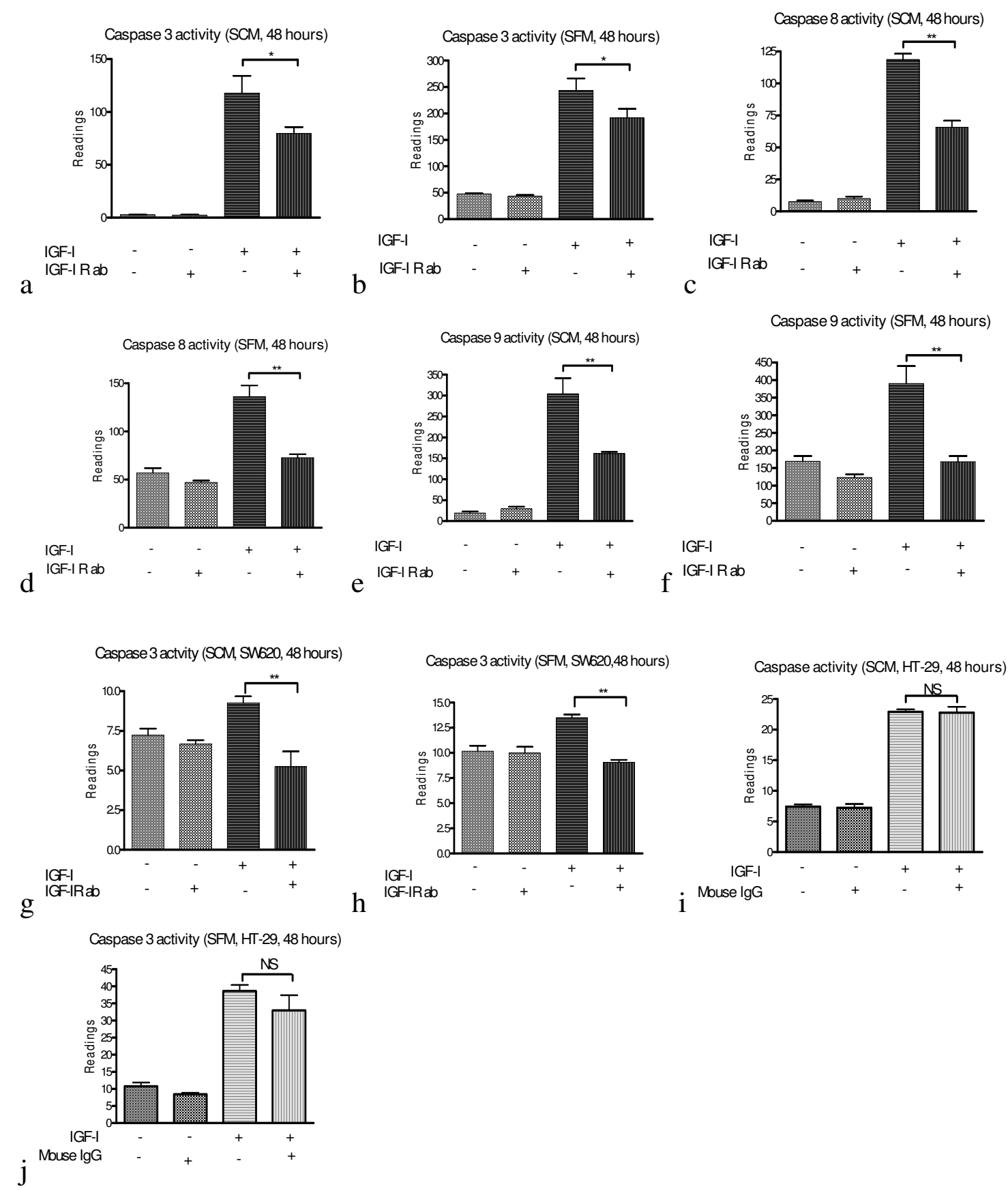

\section{Figure 3}

IGF-I -induced caspases activation is neutralised by anti-IGF-IR antibody IGF-I-induced activation of caspases 3/7 (a, b), 8 (c, d) and 9 (e, f) in HT-29 cells and caspase $3 / 7$ in SW620 cells $(g, h)$ is neutralised by anti-IGF type I receptor antibody (IGF-IR ab). Cells were pre-incubated with $(+)$ or without (-) IGF-IR ab $(400 \mathrm{ng} / \mathrm{ml})$ for 30 minutes and then treated with $(+)$ or without (-) IGF-I (50 ng/ml) for 48 hours. The cellular caspase 3/7, 8 and 9 activities were analysed with Caspase-Glo assay kit (Promega, Madison USA). To check whether any IGF-IR antibody neutralization of IGF-I action is a specific effect a general mouse lgG was included $(i, j)$. For mouse lgG control experiment cells were pre-incubated with $(+)$ or without $(-)$ mouse $\lg G$ $(400 \mathrm{ng} / \mathrm{ml})$ for 30 minutes. The caspase $3 / 7$ activity was analysed with the same method as IGF-IR ab. Significance value: $* \mathrm{P}$ $<0.05$; ** $\mathrm{P}<0.01$. SCM-serum containing media; SFM-serum free media. 
data show that the caspase $3 / 7,8$ and 9 activation by IGFI can be inhibited by interfering in the binding between IGF-I and its receptors and indicate that IGF-I activates caspases $3 / 7,8$ and 9 in HT-29 cells via interaction between IGF-I and its receptors. In SCM medium (figure $3 a, c$ and 3e) IGF-IR ab did not affect caspase $3 / 7,8$ or 9 activity if the medium did not include exogenous IGF-I compared to untreated groups. However, in SFM medium the caspase 8 (figure $3 \mathrm{~d}$ ) and 9 (figure $3 \mathrm{f}$ ) activities tend to be lower in IGF-IR ab treated group compared to untreated groups, although these differences did not reach a statistically significant level. The same effect of blocking the IGF-I receptor with IGF-I $\mathrm{R}$ ab was also shown in SW620 cells (figure $3 \mathrm{~g}$ and $3 \mathrm{~h}$ ). When IGF-IR ab was included in SW620 cells, the caspase 3/7 activities significantly decreased $(\mathrm{P}<0.01)$ in both SCM (figure $3 \mathrm{~g})$ and SFM (figure $3 \mathrm{~h}$ ) media compared to IGF-I treated groups. In order to check whether IGF-IR antibody neutralization of IGF-I action is a specific effect; a general mouse IgG was included in the experiment. The results (figure $3 \mathrm{i}$ and $3 \mathrm{j}$ ) showed that general mouse IgG was not able to inhibit IGF-I induced caspase activation. This indicates that IGFIR antibody effect is a specific action.

\section{Establishment of cell death assay for colorectal cancer cell lines (HT-29, SW620 and HCTII6)}

After treatment with different concentration of 5-FU, death indexes of HT-29, SW620 and HCT116 cells are shown in figure $4 \mathrm{a}, \mathrm{b}$ and $4 \mathrm{c}$ respectively. Although all three cell lines' death index increased in a dose responsive manner along with the increases of 5-FU concentrations, it is interesting to note that the three colorectal cell lines have different sensitivities to the treatments of 5-FU. While HCT116 cells have the most sensitive responses to 5-FU treatment (figure 4c), HT-29 and SW620 cells only show modest response (figure a and $\mathrm{b}$ ). These different responses may be due to the divergent genetic background of these cells. HCT116 cell is a p53 wild type of colorectal cancer cell line while HT-29 and SW620 cells contain mutated p53 genes (table 1). Both pre-clinical and clinical studies have shown that disruption of p53 function contributes to 5-FU resistance[23,24]. Never the less, the results have indicated that the death assay can truly represent the actual cell death in each treatment. This death assay method has been successfully used to determine the apoptotic cell death for HT-29 D4, HCT116 and SW620 cells [13]. It is therefore suitable for assessment of cell death in HT-29, SW620 HCT116 cells.

\section{IGF-I activation of caspases 3/7, 8 and 9 in colon cancer cells does not induce cell death}

To further examine whether IGF-I activation of caspases 3/ 7,8 and 9 increases apoptosis in colon cancer cells, HT29, SW620 and HCT116 cells were treated with IGF-I (100 $\mathrm{ng} / \mathrm{ml}$ ) in SCM and SFM conditions respectively for 48 hours. The cell death index was then determined using our established method. The results are shown in figure $4 \mathrm{~d}$, e and $4 \mathrm{f}$. It can be seen that cell death is not influenced by exogenous IGF-I at a $100 \mathrm{ng} / \mathrm{ml}$ concentration for all three cell lines in SCM and SFM conditions, even though this concentration of IGF-I significantly increase caspase 3/7, 8 and 9 activities in these cell lines (figure 1 and 2). To further confirm that cell death is not induced by caspase activation a previously reported cell viability assessment [12] was used to examine cell survival after treatment with exogenous IGF-I. The results are shown in figure $4 \mathrm{~g}, \mathrm{~h}$ and $4 \mathrm{i}$. It can again be seen that cell survival is not significantly different between IGF-I treated and untreated cells in SCM and SFM conditions. These results indicate that IGF-I induced caspase activation alone is not able to be transformed to the ultimate death signal in these colon cancer cells.

\section{Inhibition of caspase activation induced by IGF-I does not affect cell proliferation}

To investigate whether IGF-I-induced caspase activation has any effect on cancer cell proliferation, caspase activation induced by IGF-I was inhibited by incubation with ZVAD-FMK (a general caspase inhibitor). It was shown that Z-VAD-FMK indeed was able to inhibit caspase 3 activation in HT-29 (figure 5a), SW620 (figure 5c) and HCT116 cells (figure 5e). But this inhibition has no effect on these cell lines' proliferation (figure $b, d$ and $f$ ). These indicate that IGF-I-induced caspase activation has no effect on these cancer cells' proliferation.

\section{Discussion}

IGF-I signalling through the IGF-IR plays an important role in cellular transformation, proliferation and apoptosis of tumour cells. It has been well documented that IGFIR has the function of mitogenicity, transformation and anti-apoptosis in many cell types, both in vitro and in vivo [25-27]. In addition to the anti-apoptotic action of IGF-I, there have been several studies which demonstrated that IGF-I can also be pro-apoptotic in colon cancer cells [13], skeletal myoblasts [16], preadipocytes [14], fibroblasts [15] and osteosarcoma cells [28]. The mechanisms by which IGF-I enhances apoptosis in these cells are still largely unclear. This study examined the relation of exogenous IGF-I and the activities of caspase 3/7, 8 and 9 in three colorectal cancer cell lines and one skeletal muscle cell line. It was found that exogenous IGF-I can activate caspases $3 / 7,8$ and 9 in all four cell lines, and that the activation is via the IGF-I receptor. The four cell lines used in the experiments have a variety of cellular properties including cell species, tissue type, cell type and gene mutations (table 1), nevertheless, IGF-I universally increased caspase activities in all of these cell lines, indicating that caspase activation by exogenous IGF-I is a global effect in all these cells. 


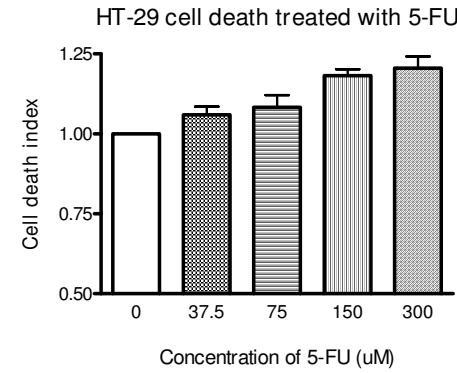

a

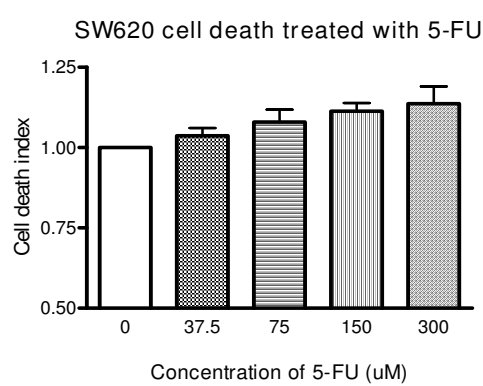

b

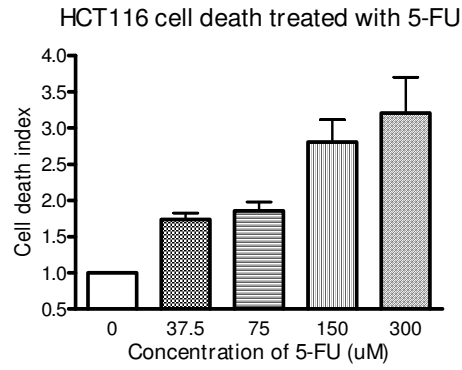

C

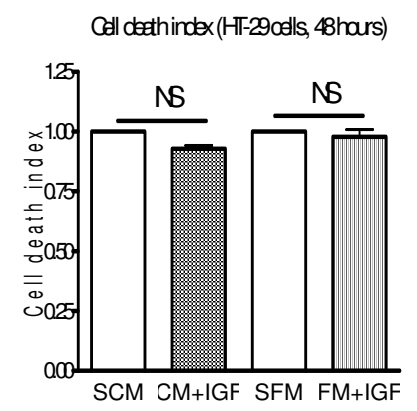

d

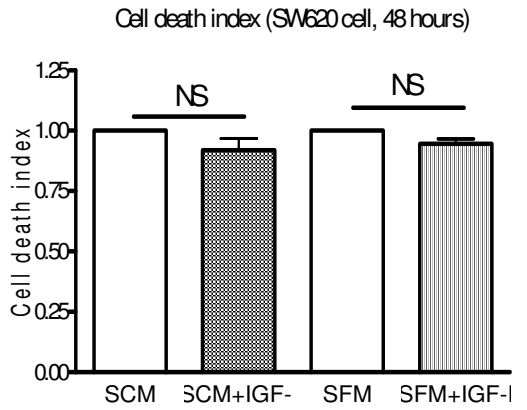

$\mathrm{e}$
Cell death index (SCT116 cell, 48 hours)

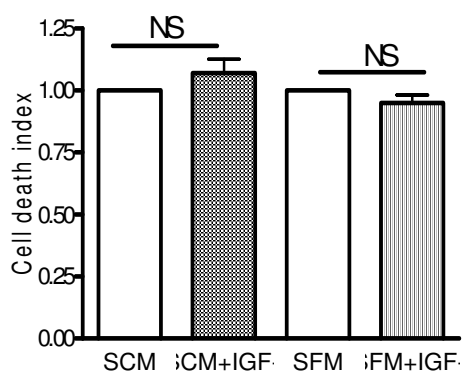

f

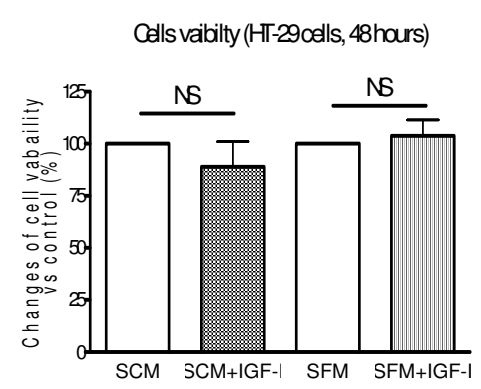

g

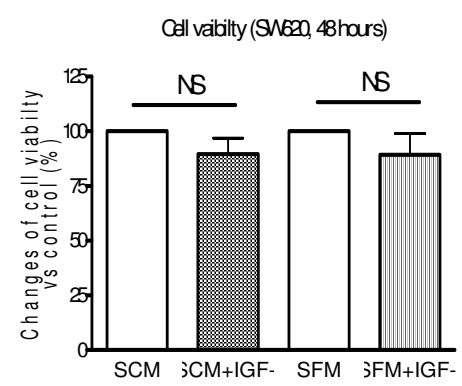

h

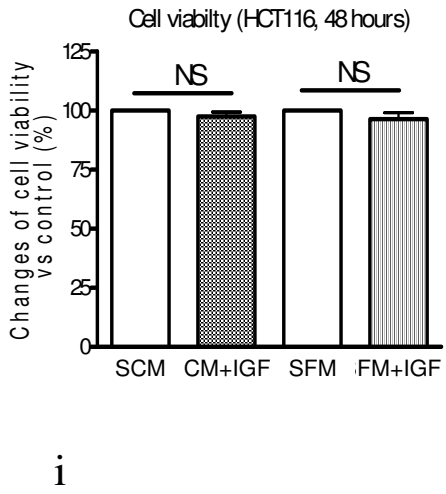

\section{Figure 4}

Exogenous IGF-I dose nod change cell death and viability in HT-29, SW620 and HCTII6 cells. HT-29 (a), SW620 (b) and HCTII 6 (c) cells were treated with different concentrations of 5-Fluorouracil (5-FU) $(0,37.5,75,150$ and $300 \mu \mathrm{M})$ for 48 hours. The cell death index was determined by a previously reported method [13]. HT-29 (d), SW620 (e) and HCTII6 (f) cells were treated with IGF-I ( $100 \mathrm{ng} / \mathrm{ml})$ for 48 hours and cell death index was determined with the same method. HT-29 (g), SW620 (h) and HCTII6 (i) cells were treated with IGF-I ( $100 \mathrm{ng} / \mathrm{ml})$ for 48 hours and cell viability was determined by a previously reported cell proliferation assay [20]. 
Caspase3/7 activity, HT-29 cell

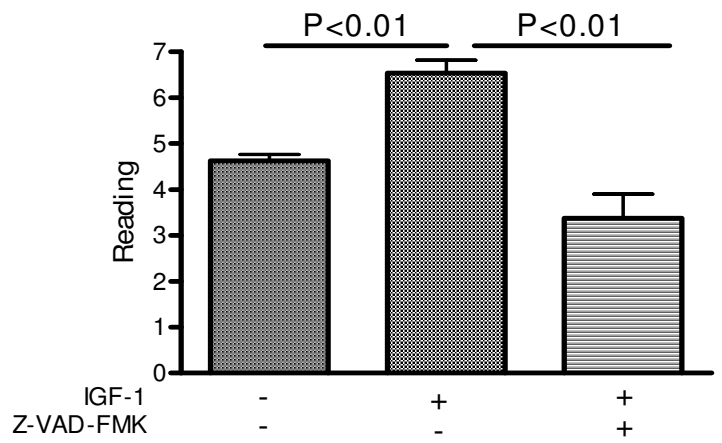

a

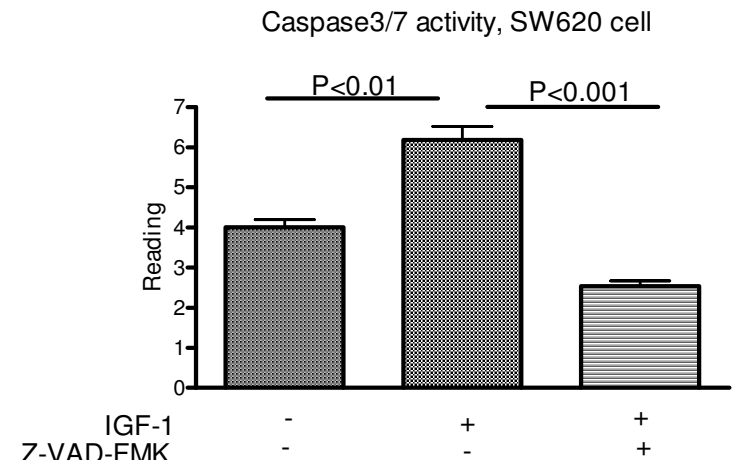

C

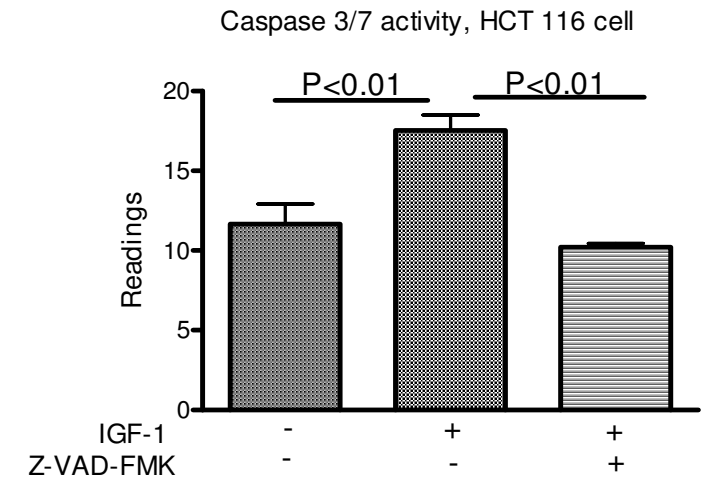

e cell proliferation, HT-29 cell

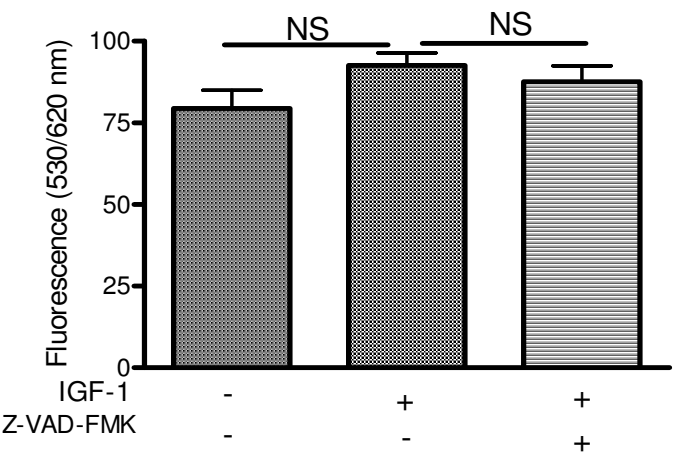

b

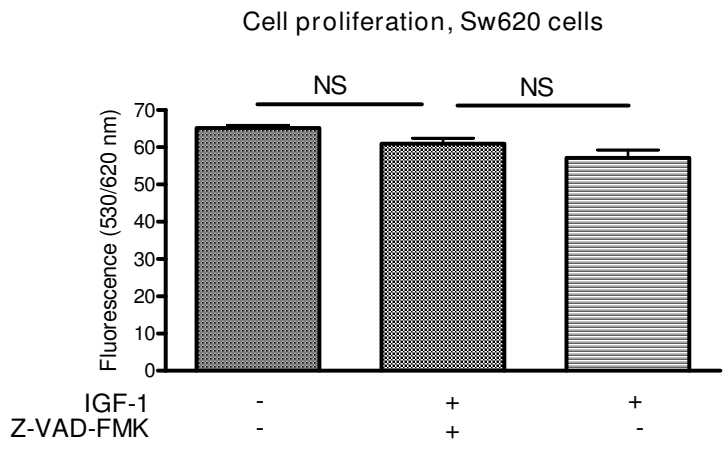

$\mathrm{d}$

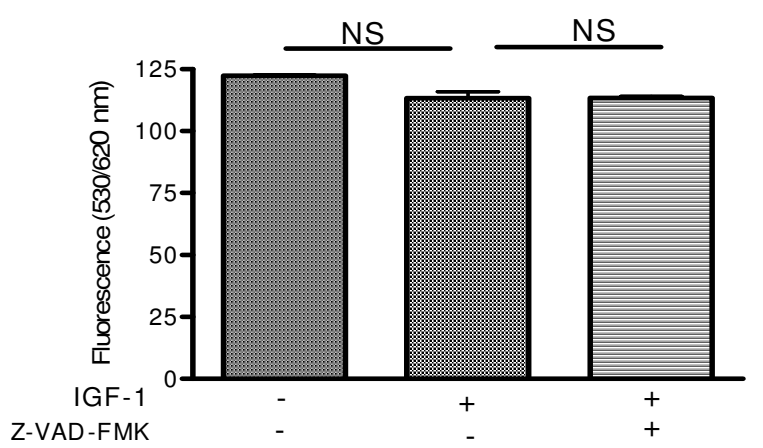

f

\section{Figure 5}

Inhibition of IGF-I-induced caspases activation does not affect colorectal cancer cell proliferation. The IGF-Iinduced caspase activation is inhibited by incubation with Z-VAD-FMK (a general caspase inhibitor) for 48 hours. The caspase 3/7 activity was measured with Caspase-Glo assay kit (Promega, Madison USA). Cell proliferation was measured with Alamar blue (Serotec Ltd, Oxford, UK). It was shown that Z-VAD-FMK indeed was able to inhibit caspase 3 activation in HT-29 (a), SW620 (c) and HCTII6 cells (e). But the inhibition has no effect on cell proliferation (b, $d$ and ff). 
Mutational analyses of the IGF-IR have shown that mitogenicity and transforming activity of IGF-IR are localized on separate domains [29-31]. Point mutation in the $\mathrm{C}$ terminal of IGF-IR abolished its anti-apoptosis and transformation action, but left its mitogenic action intact $[29,32]$. Although the molecular mechanism related to pro-apoptotic action of IGF-I R remain unclear, expression of the IGF-IR $\mathrm{C}$ terminal as a myristylated protein caused massive cell death [33] indicating IGF-IR C terminal plays a critical role in regulating cell apoptosis. It has also been proposed that segregation of IGF-IR in and out of membrane lipid rafts may regulate the pro and antiapoptotic effects of IGF-I [13]. The finding that IGF-I activation of caspases in colorectal cancer and C2C12 cells can be inhibited by blocking IGF-I binding to IGF-IR receptor in this study shows that IGF-IR indeed is involved in regulation of IGF-I-induced caspase activation. It is interesting to note that in some conditions IGF-I R ab only partially inhibit IGF-I induced caspase activation and inhibition effect is more effective in SFM conditions than in SCM conditions (figure 3). This indicates that there may be another receptor or growth factor which is involved in the caspase activation.

Although it is widely assumed that the apoptotic death of mammalian cells is closely associated with activation of caspases, there is evidence indicating that caspase activation is also involved with processes that are not necessarily related to apoptosis. For examples, caspase 3 activity is involved with skeletal muscle differentiation [4] and when HT-29 cells are induced to the terminal differentiation caspase activation is required [5]. It has been reported that caspase activation may contribute to subtle signalling pathways, some of which may enhance cell survival and proliferation [34]. Our results showed that IGF-I activates caspases $3 / 7,8$ and 9 in colorectal cancer calls, but did not cause cell death. This indicates that caspase activation induced by exogenous IGF-I may be involved with processes not related to the apoptotic cell death. A further study is currently investigating the role of IGF-I induced caspase activation. These findings raise an important question, i.e. caspase activation is not synonymous with apoptotic death; therefore increased caspase activities can not be regarded as a sole indicator of cell death.

\section{Conclusion}

IGF-I activates caspase 3/7, 8 and 9 in three colon cancer and one skeletal muscle cell lines and IGF-IR is involved in the IGF-I induced caspase activation. IGF-I induced caspase activation is not able to be transformed to death signal; it may be involved with other processes which are not related to apoptosis.

\section{Abbreviations}

IGF-I: Insulin-like growth factor I; IGF-IR: Insulin-like growth factor type 1 receptor; IGF-IR ab: Anti Insulin-like growth factor type 1 receptor antibody; CRC: Colorectal cancer; TNF: Tumour necrosis factor; SCM: Serum-containing media; SFM: Serum-free media.

\section{Competing interests}

The authors declare that they have no competing interests.

\section{Authors' contributions}

SYY and MCW conceived the study. SYY designed the experiments, carried out the study and prepared the manuscript. CB carried out partial experiments. KMS, BF, AMS and MCW participated in the design, reviewed all data, and contribute in the preparation of the manuscript. All authors read and approved the final manuscript.

\section{Acknowledgements}

SYY has received financial support from Motor Neurone Disease Association-UK and I.O.C. World Anti Doping Agency.

\section{References}

I. Rajagopalan H, Nowak MA, Vogelstein B, Lengauer C: The significance of unstable chromosomes in colorectal cancer. Nat Rev Cancer 2003, 3:695-70I.

2. Labianca R, Pessi MA, Zamparelli G: Treatment of colorectal cancer. Current guidelines and future prospects for drug therapy. Drugs 1997, 53:593-607.

3. Magnuson BA, Raju RV, Moyana TN, Sharma RK: Increased N-myristoyltransferase activity observed in rat and human colonic tumors. J Natl Cancer Inst 1995, 87:1630-1635.

4. Fernando P, Kelly JF, Balazsi K, Slack RS, Megeney LA: Caspase 3 activity is required for skeletal muscle differentiation. Proceedings of the National Academy of Sciences of the United States of America 2002, 99: I 1025-1 I030.

5. Cai JY, Chen Y, Murphy TJ, Jones DP, Sartorelli AC: Role of caspase activation in butyrate-induced terminal differentiation of HT29 colon carcinoma cells. Archives of Biochemistry and Biophysics 2004, 424:119-127.

6. Launay S, Hermine O, Fontenay M, Kroemer G, Solary E, Garrido C: Vital functions for lethal caspases. Oncogene 2005, 24:5|37-5|48.

7. Drucker DJ: Epithelial cell growth and differentiation. I. Intestinal growth factors. Am J Physiol 1997, 273:G3-G6.

8. Baserga R, Peruzzi F, Reiss K: The igf-I receptor in cancer biology. International Journal of Cancer 2003, 107:873-877.

9. Surmacz E: Growth factor receptors as therapeutic targets: strategies to inhibit the insulin-like growth factor I receptor. Oncogene 2003, 22:6589-6597.

10. Werner H, Le Roith $D$ : New concepts in regulation and function of the insulin-like growth factors: implications for understanding normal growth and neoplasia. Cellular and Molecular Life Sciences 2000, 57:932-942.

II. Remacle-Bonnet MM, Garrouste FL, Heller S, Andre F, Marvaldi JL, Pommier GJ: Insulin-like growth factor-I protects colon cancer cells from death factor-induced apoptosis by potentiating tumor necrosis factor alpha-induced mitogen-activated protein kinase and nuclear factor kappaB signaling pathways. Cancer Res 2000, 60:2007-2017.

12. Yang SY, Sales KM, Fuller BJ, Seifalian AM, Winslet MC: Inducing apoptosis of human colon cancer cells by an IGF-I D domain analogue peptide. Molecular Cancer 2008, 7:17.

13. Remacle-Bonnet M, Garrouste F, Baillat G, Andre F, Marvaldi J, Pommier G: Membrane rafts segregate pro- from anti-apoptotic insulin-like growth factor-I receptor signaling in colon carcinoma cells stimulated by members of the tumor necrosis factor superfamily. Am J Pathol 2005, 167:761-773. 
14. Niesler CU, Urso B, Prins JB, Siddle K: IGF-I inhibits apoptosis induced by serum withdrawal, but potentiates TNF-alphainduced apoptosis, in 3T3-LI preadipocytes. Journal of Endocrinology 2000, I 67: 165-174.

15. Seto J, Seto Y, lino M, Komatsu T, Katagiri K, Hagino A, Aso H, Katoh $\mathrm{K}$, Sasaki $Y$, Obara $Y$ : IGF-I-induced apoptosis in LM2d6 cultured at a low concentration of fetal bovine serum. Cell Biology International 2001, 25:893-899.

16. Foulstone EJ, Meadows KA, Holly JMP, Stewart CEH: Insulin-like growth factors (IGF-I and IGF-II) inhibit C2 skeletal myoblast differentiation and enhance TNF alpha-induced apoptosis. Journal of Cellular Physiology 200I, I 89:207-2I 5 .

17. Adamsen BL, Kravik KL, Clausen OP, De Angelis PM: Apoptosis, cell cycle progression and gene expression in TP53-depleted HCTII6 colon cancer cells in response to short-term 5 fluorouracil treatment. Int J Oncol 2007, 3 I: |49|-|500.

18. Ashktorab H, Dawkins FW, Mohamed R, Larbi D, Smoot DT: Apoptosis induced by aspirin and 5 -fluorouracil in human colonic adenocarcinoma cells. Digestive Diseases and Sciences 2005, 50:1025-1032.

19. Ciccolini J, Peillard L, Evrard A, Cuq P, Aubert C, Pelegrin A, For mento P, Milano G, Catalin J: Enhanced antitumor activity of 5 fluorouracil in combination with 2 '-deoxyinosine in human colorectal cell lines and human colon tumor xenografts. Clinical Cancer Research 2000, 6: I529-I535.

20. Wesierska-Gadek J, Gueorguieva M, Ranftler C, Zerza-Schnitzhofer $\mathrm{G}$ : A new multiplex assay allowing simultaneous detection of the inhibition of cell proliferation and induction of cell death. J Cell Biochem 2005, 96: I-7.

21. da Silva PA, Boffo MM, de MI, Silva AB, Palomino JC, Martin A, Takiff $\mathrm{HE}$ : Comparison of redox and D29 phage methods for detection of isoniazid and rifampicin resistance in Mycobacterium tuberculosis. Clin Microbiol Infect 2006, 1 2:293-296.

22. Green DR, Reed JC: Mitochondria and apoptosis. Science 1998, 28 I: |309-|3|2

23. Elsaleh H, Powell B, McCaul K, Grieu F, Grant R, Joseph D, lacopetta $\mathrm{B}$ : P53 alteration and microsatellite instability have predictive value for survival benefit from chemotherapy in stage III colorectal carcinoma. Clin Cancer Res 200 I, 7: I343-1349.

24. Longley DB, Boyer J, Allen WL, Latif T, Ferguson PR, Maxwell PJ, McDermott U, Lynch M, Harkin DP, Johnston PG: The role of thymidylate synthase induction in modulating p53-regulated gene expression in response to 5-fluorouracil and antifolates. Cancer Res 2002, 62:2644-2649.

25. Baserga R, Resnicoff M, Dews M: The IGF-I receptor and cancer. Endocrine 1997, 7:99-102.

26. Baserga $R$, Resnicoff $M$, DAmbrosio $C$, Valentinis $B$ : The role of the IGF-I receptor in apoptosis. Vitamins and Hormones - Advances in Research and Applications 1997, 53:65-98.

27. Baserga R, Hongo A, Rubini M, Prisco M, Valentinis B: The IGF-I receptor in cell growth, transformation and apoptosis. Biochimica et Biophysica Acta-Reviews on Cancer 1997, I332:FI 05-FI 26.

28. Raile K, Hille R, Laue S, Schulz A, Pfeifer G, Horn F, Kiess W: Insulinlike growth factor I (IGF-I) stimulates proliferation but also increases caspase-3 activity, annexin-V binding, and DNAfragmentation in human MG63 osteosarcoma cells: Co-activation of pro- and anti-apoptotic pathways by IGF-I. Hormone and Metabolic Research 2003, 35:786-793.

29. Hongo A, DAmbrosio C, Miura M, Morrione A, Baserga R: Mutational analysis of the mitogenic and transforming activities of the insulin-like growth factor I receptor. Oncogene 1996, | 2: $|23|-1238$.

30. Li SW, Resnicoff M, Baserga R: Effect of mutations at serines | 280-| 283 on the mitogenic and transforming activities of the insulin-like growth factor I receptor. Journal of Biological Chemistry 1996, 271:12254-12260.

31. Surmacz E, Sell C, Swantek J, Kato H, Roberts CT, Leroith D, Baserga $\mathrm{R}$ : Dissociation of Mitogenesis and Transforming Activity by C-Terminal Truncation of the Insulin-Like Growth-Factor-I Receptor. Experimental Cell Research 1995, 2 I 8:370-380.

32. OConnor R, KauffmannZeh A, Liu YM, Lehar S, Evan GI, Baserga R, Blattler WA: Identification of domains of the insulin-like growth factor I receptor that are required for protection from apoptosis. Mol Cell Biol 1997, I 7(I):427-35.

33. Liu YM, Lehar S, Corvi C, Payne G, O'Connor R: Expression of the insulin-like growth factor I receptor $C$ terminus as a myri- stylated protein leads to induction of apoptosis in tumor cells. Cancer Research 1998, 58:570-576.

34. Perfettini JL, Kroemer G: Caspase activation is not death. Nature Immunology 2003, 4:308-3I0.

\section{Pre-publication history}

The pre-publication history for this paper can be accessed here:

http://www.biomedcentral.com/1471-2407/9/158/pre

pub
Publish with Biomed Central and every scientist can read your work free of charge

"BioMed Central will be the most significant development for disseminating the results of biomedical research in our lifetime. "

Sir Paul Nurse, Cancer Research UK

Your research papers will be:

- available free of charge to the entire biomedical community

- peer reviewed and published immediately upon acceptance

- cited in PubMed and archived on PubMed Central

- yours - you keep the copyright 